Elías Humberto Peraza Castaneda* Guillermo Aleixandre Mendizábal ${ }^{* * *}$

Recibido: 3 de octubre de 2019

Evaluación: 12 de octubre de 2020

Aprobado: 30 de julio de 2021

Artículo de investigación (C) 2021 Universidad Católica de Colombia. Facultad de Ciencias Económicas y Administrativas. Todos los derechos reservados

*Ph.D. in Economics. Chief of Research in Educational Technologies, Ministry of Education, Science and Technology, San Salvador, El Salvador. Email: elias.peraza@ mined.gob.sv.

(D) https://orcid.org0000-0003-1900-0513

** Ph.D. in Economics. Lecturer in the Department of Applied Economics, University of Valladolid, Spain. Email: galeixam@eco.uva.es.

(D) https://orcid.org0000-0002-5352-1745
Revista Finanzas y Política Económica, Vol. 13, N. ${ }^{\circ}$ 2, julio-diciembre, 2021, pp. 439-472 https://doi.org/10.14718/revfinanzpolitecon.v13.n2.2021.7

\section{Innovation Behavior of Salvadoran Food \& Beverage Industry Firms}

\begin{abstract}
This paper presents a quantitative analysis of the external and internal determinants that affect the innovation dynamics of a low-tech sector in a less developed economy; the food \& beverage $(F \& B)$ industry in El Salvador. The empirical framework relies on a multivariate probit analysis applied to data from El Salvador's First National Innovation Survey 2013. The results show that $R \& D$ activities, use of industrial protection by $\mathrm{F} \& \mathrm{~B}$ industry firms as well as relationships between firms and knowledge agents are useful for technological innovations while the qualifications of firms' workforce and the relationships between firms and value chain agents prove useful for non-technological innovations. In addition, firms can take advantage of their size and location in the department of San Salvador to promote product innovation, whereas firms' maturity is seen to be a disadvantage. Based on the results to emerge, the role that public science, technology and innovation (STI) policies as well as STI business strategies can play in the Salvadoran agri-food industry innovation system is seen to be huge.
\end{abstract}

Keywords: sectorial innovation system, food \& beverage industry, El Salvador, multivariate probit model, innovation determinants.

JEL Classification: L66, O32, O38, O54 


\section{Comportamiento innovador de las empresas de la industria salvadoreña de alimentos y bebidas}

\section{Resumen}

Este artículo presenta un análisis cuantitativo sobre los determinantes externos e internos que afectan la dinámica de innovación de un sector de baja tecnología en una economía poco desarrollada, la industria de alimentos y bebidas $(A \& B)$ en El Salvador. El marco empírico se basa en un análisis multivariate probit aplicado a datos de la 1ํㅡㄹ Encuesta Nacional de Innovación 2013 de El Salvador. Los resultados muestran que la realización de actividades de $\mathrm{I}+\mathrm{D}+\mathrm{i}$, su correspondiente protección industrial por parte de las empresas de $A \& B$ y las relaciones con los agentes del conocimiento son especialmente útiles para sus innovaciones tecnológicas, mientras que la cualificación de su fuerza laboral y las relaciones con los agentes de la cadena de valor para sus innovaciones no tecnológicas. Además, pueden aprovechar la dimensión y su ubicación en el departamento de San Salvador para promover la innovación de producto, mientras la madurez de la empresa es una desventaja. Con base en los resultados anteriores, el papel que pueden jugar las políticas públicas de ciencia, tecnología e innovación (CTI) y las estrategias comerciales de CTI en el sistema de innovación de la industria de alimentos y bebidas salvadoreña es enorme.

Palabras Clave: Sistema Sectorial de Innovación, industria de alimentos y bebidas, El Salvador, modelo multivariate probit, determinantes de la innovación. 


\section{INTRODUCTION}

The study of innovative behavior determinants is an active and growing field of research given that innovation has become synonymous with achieving sustainable competitive advantage for firms. From an evolutionary perspective, firms are responsible for innovating while it is the market that executes the natural selection function (Nelson \& Winter, 1982). However, the enterprise does not undertake this activity alone, but draws on the support of other market and non-market organizations, i.e., it acts within an innovation system (Fundación COTEC, 2009). Bearing in mind sectoral differences of innovation processes (Pavitt, 1984), one useful notion of the innovation system is the sectoral one that emphasizes the importance of firms' knowledge base and learning mode in a particular industry (Malerba, 2004).

Sectoral and regional studies on innovation systems have been carried out in both developed and developing countries. For Central American countries, Orozco (2014) studied the coffee and palm oil sectors in Costa Rica; Orozco-Barrantes and Barboza-Arias (2018) analyzed the dairy sector in Costa Rica; and Gu, Adeoti, Castro, Orozco, and Díaz (2012) compared the coffee sector in Costa Rica to other agri-food activities in other catching-up economies. In the case of El Salvador, Cummings (2016) identifies different types of emerging innovative dynamism among local actors who had started to show their organizational capacity in the early 20th century (Cummings, 2007). The technological trajectories of several countries in this region are largely defined by their agri-export past, which has shaped their industrial development with a strong participation of food and beverage (F\&B) activities (Hoselitz, 1954; Padilla Pérez, 2013; Soluri, 2009). Specifically, the Salvadoran F\&B industry accounted for 9.09\% of the country's economy in 2016 and displayed a dynamic export performance, with $16.28 \%$ of all exports stemming from the F\&B industry in 2019. ${ }^{1}$

In an effort to gain a better understanding of the behavior of Salvadoran F\&B industry firms within their sectoral innovation system a multivariate probit analysis was carried out with two objectives: firstly, to identify the specific innovation determinants in the F\&B industry, given its specific characteristics; secondly, to test the relevance of using this quantitative methodology for analyzing the innovative behavior of firms in less developed countries, such as El Salvador, so as to enrich studies on innovation systems already carried out in other Latin-American countries (Dutrénit \& Sutz, 2014). Although STI policies have been studied intensively for the

1 Latest data available in BCR: the first is until 2016 since the series with constant prices are used. 
Latin American context (Arocena \& Sutz, 2000; Crespi \& Dutrénit, 2014), the results of this analysis may prove to be valuable both for the Salvadoran government, by adding some national and sectorial specificities to the definition and implementation of its STI policies, and also for enterprises who are striving to enhance their competitiveness through innovation. This is in line with the need of "tropicalizing" policies noted by Arocena, Göransson, and Sutz (2015) and Dutrénit and Sutz (2014)."

The paper is organized as follows: the "Innovation behavior determinants in the food and beverage industry" section summarizes the literature relevant to this research; the "Food \& beverage industry in El Salvador" section provides a brief description of Salvadoran F\&B industry activities; the "Empirical model, data and estimation method" section explains the model used to analyze the influence of the different determinants of innovation according to its typology and describes the dataset; the "Results of the econometric analysis" section presents the outcomes to emerge from the multivariate probit model; the "Discussion of main results" section offers an explanation of the empirical model's results following the literature on the economics of innovation with regard to the determinants that proved significant; finally, the "Conclusions" section provides a summary of the previous section together with STI public policy recommendations and business strategies to improve the innovation performance of the Salvadoran food and beverage industry as a whole.

\section{INNOVATION BEHAVIOR DETERMINANTS IN THE FOOD AND BEVERAGE INDUSTRY}

One important line of research in innovation dynamics involves analyzing innovation determinants (Damanpour, Walker, \& Avellaneda, 2009), and their application to the F\&B industry is no exception. There is extensive literature on these determinants of firm innovation processes, distinguishing between internal and external determinants (Águila Obra \& Padilla Meléndez, 2010; Vega Jurado, Gutiérrez Gracia, Fernández de Lucio, \& Manjarrés Henríquez, 2008). Internal determinants are linked to the specific features of organizations (Galende \& Fuente, 2003). Hence, some of these determinants are, to a certain extent, under the control of the organization and are therefore directly affected by business decisions (Hadjimanolis, 2000). From a business strategy approach, all the external factors, as well as some internal factors, in other words those which may not easily be changed by firms' managers, are opportunities and threats, which affect all organizations likewise, while internal factors that can be altered by managers are strengths and weaknesses. 
The internal factors recognized as determinants of innovative business activity include the following:

- Business dimension, measured in terms of the number of employees or annual turnover, is traditionally seen as a favorable determinant of innovative behavior in firms, although research has not always yielded conclusive results. Damanpour (1992) finds a positive relation between size and innovation, although with several moderating factors. Camisón Zornoza, Lapiedra Alcamí, Segarra Ciprés, and Boronat Navarro (2004) report similar results, particularly with regard to product innovation. In contrast, Bhaskaran (2006) holds that SMEs in some industries, where incremental innovations are frequent, e.g. the F\&B industry, are quickly able to implement innovations.

- Companies' human capital is considered to have a positive effect on firms' innovative behavior, and a direct and positive relationship can be established between human capital formation, innovation and business competitiveness (Galende \& Fuente, 2003; Peraza Castaneda, Gómez García, \& Aleixandre Mendizábal, 2016), which also reduces training costs (Bartel \& Sicherman, 1998). This positive relationship can be explained by the greater capacity to absorb scientific-technological knowledge shown by companies who boast greater human capital, as Suárez, Yoguel, Robert, and Barletta (2014) and Moncaut, Robert, and Yoguel (2017) have demonstrated for the case of Argentina. This factor is relevant not only for technological but also for non-technological innovation, especially organizational innovation (Huerta Arribas, Bayo Moriones, García Olaverri, \& Merino Díaz de Cerio, 2003).

- Company age is often considered to be a determinant of firms' innovative behavior. In most cases, young companies are seen to display greater innovative propensity (Do, 2014; Huergo \& Jaumandreu, 2004; Molero Zayas \& Buesa Blanco, 1996).

- Export propensity, measured by the proportion of overseas sales, posits the existence of a possible link between innovation and the characteristics of the market in which the firm operates. In this regard, Nassimbeni (2001) and Wakelin (1998) indicate that companies who innovate tend to have a 
greater share of exports and, simultaneously, that exporting firms improve their ability to innovate and to remain competitive. ${ }^{2}$

- Presence of foreign capital in firms is also often considered as a favorable determinant of innovative potential, as technology transfer processes from parent companies located abroad can enrich local technology capabilities (Almeida \& Phene, 2004; Tolentino, 1993). This effect is expected to be greater in developing countries, since foreign investors are usually located in more technology-developed territories. Moreover, the presence of foreign capital is associated with a greater capacity for financial leverage and with less sensitivity to a longer return on investment period. Nevertheless, there is heterogeneity in this regard. This logic holds true for manufacturing companies in countries such as Argentina, Panama, and Uruguay, although this is not always the case. De Fuentes, Dutrénit, Santiago, and Gras (2015) show that foreign ownership in Mexico has a negative effect on a firm's decision to invest in innovation given its strategy of focusing on adapting existing products to the local market. In a similar vein, Pessoa de Matos, Borin, Cassiolato, de Arruda, and Sanchez Marcellino (2016) suggest that, in less developed countries (Brazil), the strategy of foreign capital can sometimes block local dynamics when designing the distribution of global value chain activities.

- $\quad$ R\&D capacity is a determinant that has a major impact on innovation as it is a source of knowledge that gives firms a sustainable competitive advantage over competitors (Águila Obra \& Padilla Meléndez, 2010; Galende $\&$ Fuente, 2003). One indicator of this capacity is R\&D expenditure. Some authors link this kind of expenditure to technological innovation -product or process- (Calvo, 2005), although its correlation may also be relevant with non-technological innovation (Bhargava, Chatterjee, Grimpe, \& Sofka, 2011). Applying a theoretical model, Griffith, Redding, and Van Reenen (2003) identify three key sources of productivity growth (two of which are linked to R\&D): R\&D-induced innovation, technology transfer, and R\&D-based absorptive capacity (Cohen, 1990).

- Use of industrial property protection systems to ensure R\&D appropriation is closely connected with innovation activities (Archibugi \& Pianta, 1996; Barros, 2015). This factor is positively associated with different kinds of innovation, particularly product and process innovation in medium or

2 In order to avoid endogeneity issues, it is convenient to delay export data in relation to innovative performance. 
high-tech sectors (Blackburn, 2003), although it can also prove relevant for marketing in low-tech sectors (Ruiz López \& Colin Salgado, 2010). Both tendencies are present in the innovation dynamics of developing countries (Chen \& Puttitanun, 2005).

- Use of different sources of information to innovate, and use of cooperation as a way to innovate are relevant factors, such that management of knowledge and firm relationships in sectoral innovation systems can be of great importance vis-à-vis explaining how firms innovate (Malerba, 2002). In this respect, innovation economy literature recognizes its positive correlation with both product and process innovations (Un \& Asakawa, 2015; Un, Cuervo-Cazurra, \& Asakawa, 2010) as well as non-technological innovations (Pippel, 2014). Within these sources, it is possible to distinguish two complementary alternatives: internal to the firm, or to a holding of enterprises that a firm belongs to; or external to the firm and its group. In the latter, two types of agents can interact with firm: value chain agents and knowledge agents. The first group comprises enterprises in the value chains: competitors (horizontally) and suppliers and customers (vertically). The second group consists of external knowledge agents, such as universities, technology centers, laboratories, R\&D consultants, technological parks, etc. This latter type of cooperation is also referred to as institutional cooperation (Belderbos, Carree, Diederen, Lokshin, \& Veugelers, 2004; Belderbos, Carree, \& Lokshin, 2004).

The main external determinant that can influence innovative business performance is the existence of different agglomeration economies. These economies refer to externalities that are produced by a spatial concentration of economic activity or to different types of production factors, with two kinds usually being identified: location and urbanization (Polése, 1998).

- Urbanization economies are associated with advantages for firms due to their being located in an urban environment. These derive from the existence of high demand for goods and services, sophisticated labor and financial markets, the presence of generic infrastructures and, in general, the possibility of establishing relations with different organizations and companies (Camagni, 2005). In less developed countries, where the population and economic activity tend to be concentrated in just a few major cities, this type of externalities can exert a key positive influence on companies' innovative behavior (Duranton, 2014). Variables that can 
reflect information on these topics are population density and population growth, business density or evolution of employment.

- Localization economies are linked to the presence of externalities generated by the physical proximity of companies involved in the same industry and derive from the existence of specialization in the labor market and financial intermediaries, or in the supplier base (Becattini, 1990). Variables that reflect information on this type of economy are breakdown of employment, with particular focus on industrial percentage, and the evolution of industrial employment.

Some of these indicators are connected with the three components of Malerba's (2004) conceptual framework of sectoral innovation systems: institutions, agents and their relationships, as well as knowledge base and learning modes. These components allow for differentiation among sectors and for their scientific-technical limits to be established (Dosi, 1988; Nelson, 1993). The use of intellectual property is connected with the institutional component, given that a sectoral system's development depends on the security of the intellectual property protection system that provides a comfortable environment for certain specific economic sectors compared to others (Dosi \& Malerba, 1996). The use of different sources of information and types of cooperation is linked to the agents and relations within the system. The latter variables, when jointly analyzed with R\&D capacity, allow a sector's learning mode to be characterized; namely, whether it is science-based or experience-based (B. T. Asheim, Lars, Moodysson, \& Jan, 2007). In the former, STI mode sectors (science, technology and innovation), firms are more likely to cooperate with knowledge agents, develop R\&D activities and attach importance to the industrial property rights system. In the latter, DUI mode sectors (doing, using and interacting), firms are more likely to cooperate with agents of their value chain, carry out few R\&D activities and attach relatively little importance to industrial property protection (Jensen, Johnson, Lorenz, \& Lundvall, 2007). The F\&B industry fits into the latter type of sector, combining a low level of R\&D investment with a strong innovative capacity, which is mainly based on accumulative incremental innovation (Rama, 2008).

\section{THE FOOD \& BEVERAGE INDUSTRY IN EL SALVADOR}

The F\&B industry is of great importance to the Salvadoran economy. Its share of GDP has remained stable over the last two decades, with the food industry 
accounting for $7.2 \%$ and the beverage industry for $1.89 \%{ }^{3}$ of GDP in 2016 . Moreover, this industry is linked to the agricultural sector, which is a core activity for much of the Salvadoran population. In the aftermath of the dramatic economic recession that followed the end of the civil war in 1992, a period of neoliberal economics, based on the Washington Consensus, boosted the trade and services sectors, but not industry. Since 2009, there has been a refocusing of economic policies, which has driven a production transformation that seeks to revitalize industry, with the F\&B sector coming very much to the fore. This new approach has gone hand in hand with efforts aimed at improving the national science and technology system (Gobierno de El Salvador, 2011, 2012; Ministerio de Economía de El Salvador, 2014).

In 2012 , the $F \& B$ industry was made up of 10,956 economic units with 45,225 employees (Table 1). These data represent $58.5 \%$ of the economic units in industry, and $33.6 \%$ of industrial employment. In global terms, this represents $6.8 \%$ of the units in the Salvadoran economy and $7.1 \%$ of those in employment.

Table 1.

Economic units and employment in the Salvadoran F\&B industry in 2012

\begin{tabular}{|c|c|c|c|c|}
\hline & \multicolumn{2}{|c|}{ Economic units } & \multicolumn{2}{c|}{ Employment } \\
\hline & Number & Percentage & Number & Percentage \\
\hline F\&B industry & 10,956 & & 45,225 & \\
\hline Industry & 18,713 & $58.5 \%$ & 134,687 & $33.6 \%$ \\
\hline Total economy & 161,934 & $6.8 \%$ & 634,514 & $7.1 \%$ \\
\hline
\end{tabular}

Source: Author's calculations, based on the Salvadoran General Directorate of Statistics and Censuses (2012) .

In 2012, this industry showed high labor productivity, which was 1.27 times the average productivity of the Salvadoran economy for the food subsector, and 6.33 times the average for the beverage subsector. In addition, the F\&B industry has a dynamic export performance, such that this industry represented $16.28 \%$ of all of El Salvador's exports in 2019. ${ }^{4}$

Regarding the innovation activities of agri-food industry, the main internal source of information to innovate is the production area, cited by $23.7 \%$ of innovative companies, followed by administration and finance and marketing areas, the R\&D department appears as a source of information in $8.2 \%$ of companies.

3 Data from the Central Reserve Bank of El Salvador: https://www.bcr.gob.sv

4 Data from the Central Reserve Bank of El Salvador: https://www.bcr.gob.sv 
The preponderance of engineering driven innovations outlines a sectoral knowledge base of synthetic nature that comes from a DUI learning mode. Regarding the use of external information sources, those related to the value chain are more relevant than those related to knowledge agents. In that sense, customers, followed by suppliers, are the main source of information to innovate, in both cases cited by more than $15 \%$ of innovative companies. The reduced presence of competitors, only $2.3 \%$ of the companies, shows a reduced presence of open innovation processes (Chesbrough, 2003) . The generation of knowledge through their R\&D activities is carried out by $23.5 \%$ of Salvadoran agri-food industrial companies, being slightly above the industry as a whole. ${ }^{5}$

The knowledge base in a sectorial innovation system comes from its workers. The composition of the human capital of companies in a given sector is a good measure of it (Jensen et al., 2007). For the Salvadoran agri-food industry, $10 \%$ of workers have completed higher education, ${ }^{6}$ being a structure closer to a DUI learning. Besides, the knowledge base of a sector can be measured using the stock of scientific-technological knowledge that are linked with the patents of the innovation system. In this regard, in El Salvador, patents related to the food sector for the period 1993 to 2015 amount to 43.7

\section{EMPIRICAL MODEL, DATA AND ESTIMATION METHOD}

The relations between the determinants of innovation and innovation behavior of Salvadoran F\&B industry firms must take account of the different types of innovation. Hence, innovation performance is measured using dummy variables for the four types of innovation identified by the Oslo manual (OCDE, 2005): product innovation (prod_innov), process innovation (proc_innov), organizational innovation (org_innov), and marketing innovation (mark_innov). ${ }^{8}$ The most frequent innovation is in product innovation, which is undertaken by $24.2 \%$ of Salvadoran F\&B industry firms, followed

$5 \quad$ Data from El Salvador's First National Innovation Survey 2013.

6 Data from El Salvador's First National Innovation Survey 2013.

7 Data from El Salvador's National Registry Center (CNR) for categories of the international patent classification relating to food and tobacco: A21, A22, A23 and A24.

8 Examples of innovation in the F\&B industry according to the OECD typology are:

- Product innovations: functional foods.

- Process innovations: systems aimed at promoting safety, traceability and quality of foods.

- Organizational innovations: establishing quality standards or knowledge management systems.

- Marketing innovations: developing new packaging or use of origin appellations. 
by process innovation, carried out by $22.1 \%$ of firms. Organizational and marketing innovations are engaged in to a lesser extent; $14.5 \%$ and $16.5 \%$, respectively.

It is reasonable to assume there are interactions among different types of innovation. ${ }^{9}$ In this sense, since types of innovation variables are dichotomous, a tetrachoric correlation matrix can reflect the links among them (Table 2). In the case of Salvadoran F\&B industry firms, product innovation (prod_innov) is associated with process and marketing innovation (proc_innov, mark_innov), and organizational innovation (org_innov) with marketing innovation (mark_innov).

Table 2.

Tetrachoric matrix of types of innovation (dependent variables)

\begin{tabular}{|c|c|c|c|c|}
\hline & prod_innov & proc_innov & org_innov & mark_innov \\
\hline prod_innov & 1.0000 & & & \\
\hline proc_innov & $0.5608^{*}$ & 1.0000 & & \\
\hline org_innov & 0.3946 & 0.1821 & 1.0000 & \\
\hline mark_innov & $0.5440^{*}$ & 0.3505 & $0.7394^{*}$ & 1.0000 \\
\hline
\end{tabular}

Note: *** significant at $1 \%$; ${ }^{* *}$ significant at $5 \%$; ${ }^{*}$ significant at $10 \%$.

Source: Author's calculations.

These results confirm the need to take into consideration the interrelated effects of different types of innovation on overall firm performance; i.e., the need to choose a multivariate probit model to analyze the determinants of innovation for Salvadoran F\&B industry firms. This method has already been used in different contexts: for Dutch industry by Belderbos, Carree, Diederen, et al. (2004), or for Spanish low-tech industry by Acosta, Coronado, and Romero (2015). For the Latin American case, key studies include De Fuentes et al. (2015) and CEPAL (2017).

For the Salvadoran F\&B industry, the data used consists of 149 observations, which is a representative sample of a universe of 349 F\&B industry firms with 10 or more employees (Table 3). This data comes from El Salvador's First National Innovation Survey 2013 (Viceministerio de Comercio e Industria, 2013), and microdata were provided by the General Directorate of Innovation and Competitiveness (Spanish acronym - DGIC).

9 If different types of innovation were independent, it would be possible to carry out a probit model for each kind of innovation (prod_innov, proc_innov, org_innov, mark_innov). In these four models, the dependent variable is a dummy variable whose value is one if the company has innovated, and zero otherwise. The results of the individual probit for each type of innovation are shown in Appendix 3. 
Table 3.

Data on Salvadoran F\&B industry firms

\begin{tabular}{|c|c|c|c|c|c|}
\hline Sector & Size & $\begin{array}{c}\text { Expansion } \\
\text { factor }\end{array}$ & Frequency & Percentage & $\begin{array}{c}\text { Represented } \\
\text { firms }\end{array}$ \\
\hline Food & Small Firm & 3.676056 & 67 & 44.97 & 246 \\
\hline Food & Medium Firm & 1.500000 & 26 & 17.45 & 39 \\
\hline Food & Big Firm & 1.297872 & 45 & 30.20 & 58 \\
\hline Beverage & Small Firm & 7.000000 & 3 & 2.01 & 21 \\
\hline Beverage & Medium Firm & 1.000000 & 3 & 2.01 & 3 \\
\hline Beverage & Big Firm & 2.200000 & 5 & 3.36 & 11 \\
\hline Total & & & 149 & 100.00 & 379 \\
\hline
\end{tabular}

Source: Author's calculations, based on the First National Innovation Survey 2013 of El Salvador.

Internal and external determinants are measured by 23 dummy variables (sixteen internal and seven external) that are linked to the factors introduced in the previous section (Appendix $1 \& 2$ ). Before the multivariate model analysis, and in order to identify which determinants have an impact in the case of the Salvadoran F\&B industry, a bivariate analysis of relations between internal and external determinants as well as different types of innovation (product, process, organizational or marketing innovation) was conducted. As a result, 16 variables related to internal determinants of innovation and four variables related to external determinants were identified (Table 4). ${ }^{10}$

The correlation between the independent variables is studied using a tetrachoric correlation matrix (Table 5). This matrix shows the correlation between variables that measure the same determinant (e.g. a firm's size measured by sales or employees) or variables that measure different determinants (e.g. sales and exports). Bearing in mind this information some variables can be discarded:

- Sales (sales_12_cat) has been chosen to measure firm size;

- The enterprise being located in the department of San Salvador, where the homonymous capital is (San_Sal_ef), represents a proxy for the effect linked to agglomeration economies;

- Cooperation relations (group_co, valuech_co and know_ag_co) are strongly associated with sources of information and provide a good measure of the

10 Selection criteria are: being associated with at least one form of innovation at $1 \%$ significance level or, alternatively, being associated with at least two forms of innovation at $5 \%$ significance level. 
workings of the innovation process (Belderbos, Carree, \& Lokshin, 2004). $\mathrm{R} \& \mathrm{D}$ activities ( $\left.R \& D_{-} a c t\right)$ are linked to the use of information sources within the firm or its group (int_so_inf);

- Use of industrial property (use_IP) is closely connected to the use of trademarks and origin appellations (use_trad_orap);

- Percentage of university employees (per_emp_uni_cat), age of firm (age cat), presence of foreign capital (for_cap_cat) and cooperation within its group (group_co), which are strongly linked to different determinants, evidence no major correlation problems with other independent variables.

Table 4.

Independent variables used in the multivariate probit model for innovation in the Salvadoran F\&B industry

\begin{tabular}{|c|c|c|c|c|c|c|c|}
\hline Variable & Description & Obs. & Weight & $\begin{array}{c}\text { Ave- } \\
\text { rage }\end{array}$ & $\begin{array}{c}\text { Standard } \\
\text { dev. }\end{array}$ & Min. & Max. \\
\hline size & Size .2012 & 149 & 379 & 0.294 & 0.456 & 0 & 1 \\
\hline sales_12_cat & Sales. 2012 & 149 & 379 & 0.387 & 0.488 & 0 & 1 \\
\hline emp_12_cat & Employees. 2012 & 149 & 379 & 0.327 & 0.470 & 0 & 1 \\
\hline per_emp_uni_cat & Percentage of university employees. 2012 & 149 & 379 & 0.580 & 0.494 & 0 & 1 \\
\hline exp_sales_10_cat & Export / sales (\%).2010 & 149 & 379 & 0.257 & 0.438 & 0 & 1 \\
\hline age_cat & Age of firm. 2012 & 149 & 379 & 0.813 & 0.391 & 0 & 1 \\
\hline R\&D_act & Performance of R\&D activities. & 149 & 379 & 0.235 & 0.425 & 0 & 1 \\
\hline use_IP & Use of patents, utility models and & 149 & 379 & 0.068 & 0.252 & 0 & 1 \\
\hline use_trad_orap & Use of trademarks and origin appellation & 149 & 379 & 0.179 & 0.384 & 0 & 1 \\
\hline for_cap_cat & Presence of foreign capital & 149 & 379 & 0.073 & 0.260 & 0 & 1 \\
\hline int_so_inf & Internal source of information & 149 & 379 & 0.348 & 0.477 & 0 & 1 \\
\hline ext_so_inf_vc & External source of information: value chain & 149 & 379 & 0.276 & 0.448 & 0 & 1 \\
\hline ext_so_inf_ka & External source of information:: knowledge & 149 & 379 & 0.150 & 0.358 & 0 & 1 \\
\hline group_co & agents & 149 & 379 & 0.047 & 0.212 & 0 & 1 \\
\hline valuech_co & Cooperation with agents of the value chain & 149 & 379 & 0.292 & 0.455 & 0 & 1 \\
\hline know_ag_co & Cooperation with knowledge agents & 149 & 379 & 0.054 & 0.227 & 0 & 1 \\
\hline San_Sal_ef & San Salvador effect & 149 & 379 & 0.513 & 0.500 & 0 & 1 \\
\hline pop_den_12_cat & Population density & 149 & 379 & 0.801 & 0.400 & 0 & 1 \\
\hline gro_emp_5a_cat & Growth of employment. 2007-2012 & 149 & 379 & 0.346 & 0.476 & 0 & 1 \\
\hline gro_ind_ & Growth of industrial employment. 2007- & 149 & 379 & 0.575 & 0.495 & 0 & 1 \\
\hline emp_5a_cat & 2012 & & & & \\
\hline
\end{tabular}

Source: Author's calculations. 
Elías Humberto Peraza Castaneda • Guillermo Aleixandre Mendizábal

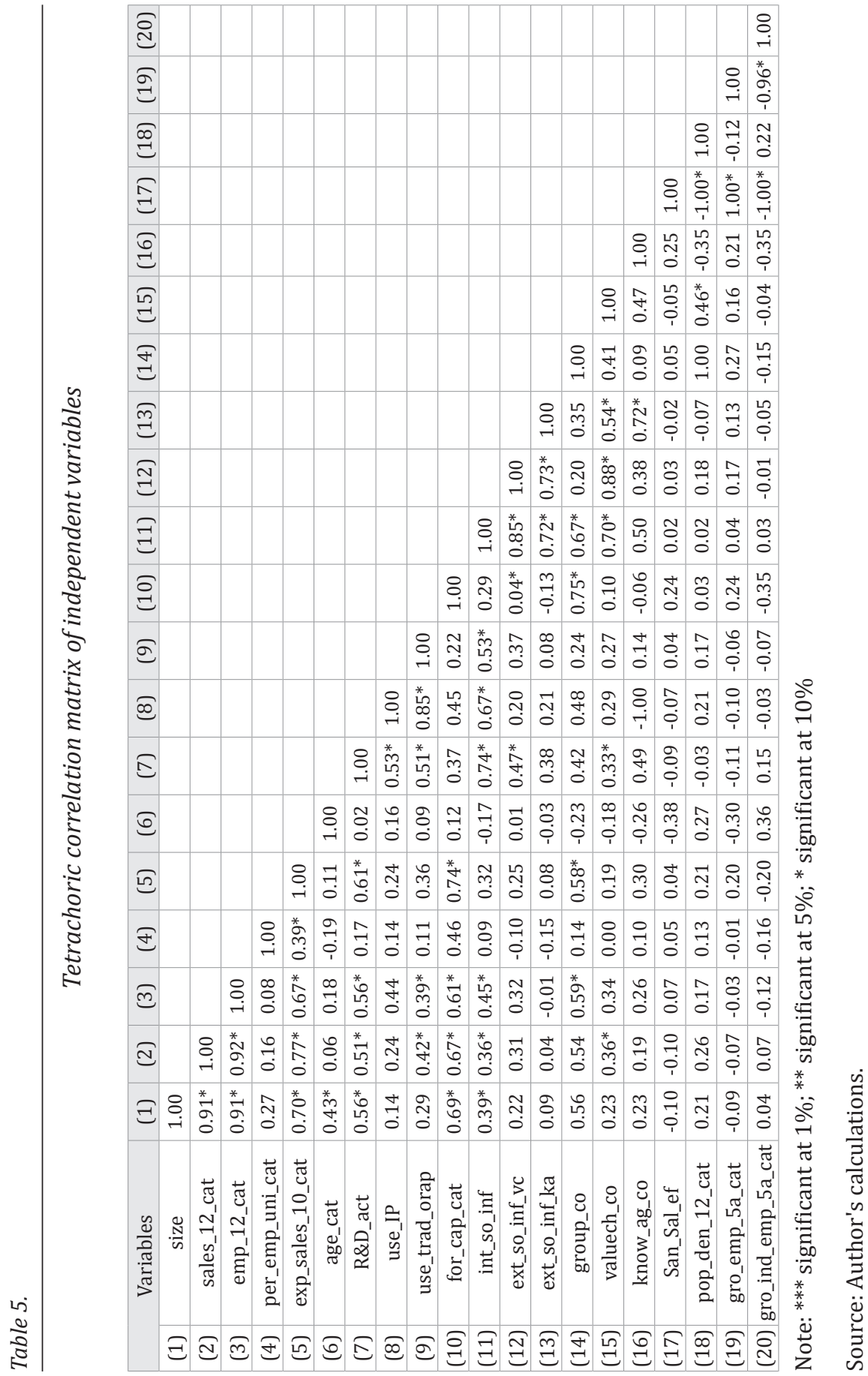


A set of 10 variables is selected following the previous process. These variables show no multicollinearity problems when conducting an analysis of the individual and mean variance inflation factor (VIF) (Table 6).

Table 6.

Multicollinearity of independent variables through VIF

\begin{tabular}{|c|c|c|c|c|}
\hline Variable & VIF & SQRT VIF & Tolerance & R-Squared \\
\hline sales_12_cat & 1.23 & 1.11 & 0.812 & 0.188 \\
\hline per_emp_uni_cat & 1.06 & 1.03 & 0.9394 & 0.0606 \\
\hline age_cat & 1.1 & 1.05 & 0.9124 & 0.0876 \\
\hline R\&D_act & 1.27 & 1.13 & 0.7862 & 0.2138 \\
\hline use_IP & 1.15 & 1.07 & 0.8704 & 0.1296 \\
\hline for_cap_cat & 1.45 & 1.2 & 0.6917 & 0.3083 \\
\hline group_co & 1.34 & 1.16 & 0.7437 & 0.2563 \\
\hline valuech_co & 1.16 & 1.08 & 0.8644 & 0.1356 \\
\hline know_ag_co & 1.14 & 1.07 & 0.8785 & 0.1215 \\
\hline San_Sal_ef & 1.09 & 1.04 & 0.9183 & 0.0817 \\
\hline Mean VIF & 1.2 & & & \\
\hline
\end{tabular}

Source: Author's calculations.

The multivariate probit analysis estimates the four dependent variables jointly

$$
y_{i, k}=\left\{\begin{array}{l}
1, \text { if } x_{i, k} \beta_{k}+\omega_{i, k}>0 \\
0, \text { otherwise }
\end{array}\right.
$$

where " $y_{i, k}$ " is a binary variable for "i" = 1,..,149 firms, "k" = 1,..,4 types of innovation. "x" reflects the independent variables, and " $\omega$ " are error terms distributed as multivariate normal, with a zero mean and variance-covariance matrix $\mathrm{V}$, having $V$ values of 1 on the main diagonal and correlations $\rho_{j, k}=\rho_{k, j}$ in the terms outside the diagonal (Capellari \& Jenkins, 2003).

\section{RESULTS OF THE ECONOMETRIC ANALYSIS}

The results of the model that estimates the four types of innovation jointly shows interdependence between them, as correlation coefficients of the error terms (rho21, rho 31, rho41, rho32, rho42 and rho43) are positive and high (Table 7). In this final model, two initial independent variables are omitted: cooperation with 
Elías Humberto Peraza Castaneda • Guillermo Aleixandre Mendizábal

the group itself (group_co) and foreign participation in the company's capital stock (for_cap_cat), as neither appear as relevant.

Table 7.

Multivariate probit model on innovation in the F\&B industry in El Salvador

\begin{tabular}{|c|c|c|c|c|c|c|c|c|}
\hline \multirow{3}{*}{ Variable } & \multirow{2}{*}{\multicolumn{2}{|c|}{$\begin{array}{c}\text { prod_innov } \\
\text { (1) }\end{array}$}} & \multirow{2}{*}{\multicolumn{2}{|c|}{$\begin{array}{c}\text { proc_innov } \\
(2)\end{array}$}} & \multirow{2}{*}{\multicolumn{2}{|c|}{$\begin{array}{c}\text { org_innov } \\
\text { (3) }\end{array}$}} & \multirow{2}{*}{\multicolumn{2}{|c|}{$\begin{array}{c}\text { mark_innov } \\
\text { (4) }\end{array}$}} \\
\hline & & & & & & & & \\
\hline & Value & Sig. & Value & Sig. & Value & Sig. & Value & Sig. \\
\hline sales_12_cat & 0.4083 & $* *$ & -0.4394 & $* *$ & -0.0001 & & 0.2137 & \\
\hline per_emp_uni_cat & -0.0271 & & 0.2083 & & 0.5239 & $* * *$ & 0.4065 & $* *$ \\
\hline age_cat & -0.6742 & $* * *$ & 0.2076 & & 0.2484 & & 0.0581 & \\
\hline R\&D_act & 1.1221 & $* * *$ & 0.7038 & $* * *$ & 0.2042 & & 0.6201 & $* * *$ \\
\hline use_IP & 1.8721 & $* * *$ & 0.6106 & $* *$ & 0.2551 & & 0.7101 & $* *$ \\
\hline valuec_co & 0.2563 & & 0.6635 & $* * *$ & 0.6696 & $* * *$ & 0.4816 & $* * *$ \\
\hline know_ag_co & 0.8039 & $* *$ & 0.9074 & $* * *$ & 0.2367 & & 0.5830 & $*$ \\
\hline San_Sal_ef & 0.4431 & $* *$ & 0.0903 & & -0.6528 & $* * *$ & 0.0327 & \\
\hline _cons & -1.2325 & $* * *$ & -1.4931 & $* * *$ & -1.6592 & $* * *$ & -1.8730 & $* * *$ \\
\hline /atrho21 & 0.2091 & $* *$ & & & & & & \\
\hline /atrho31 & 0.2178 & $*$ & & & & & & \\
\hline /atrho41 & 0.3749 & $* * *$ & & & & & & \\
\hline /atrho32 & 0.2732 & $* *$ & & & & & & \\
\hline /atrho42 & 0.3058 & $* * *$ & & & & & & \\
\hline /atrho43 & 0.6849 & $* * *$ & & & & & & \\
\hline rho21 & 0.2061 & $* *$ & & & & & & \\
\hline rho31 & 0.2144 & $*$ & & & & & & \\
\hline rho41 & 0.3583 & $* * *$ & & & & & & \\
\hline rho32 & 0.2666 & $* *$ & & & & & & \\
\hline rho42 & 0.2966 & $* * *$ & & & & & & \\
\hline rho43 & 0.5947 & $* * *$ & & & & & & \\
\hline Pearson-chi2(6) & 51.84 & & & & & & & \\
\hline Prob>chi2 & 0.000 & & & & & & & \\
\hline
\end{tabular}

Note: ${ }^{* *}$ significant at $1 \%$; ${ }^{* *}$ significant at $5 \%$; $^{*}$ significant at $10 \%$.

Source: Author's calculations.

From the results of the model, it is possible to identify relevant factors for different types of innovation (Table 7). In the case of product innovation (prod_innov, column 1), three significant explanatory variables are identified at $1 \%$ significance, with two of them displaying positive values of their coefficients: R\&D activities $\left(R \& D_{-} a c t\right)$, and use of industrial property (use_IP); while the latter, age of the firm (age_cat) has a negative value. With a significance of $5 \%$ and a positive sign, there 
are three variables related to this type of innovation: size of firms by turnover ( $\mathrm{sa}$ les_12_cat), cooperation with knowledge agents (know_ag_co), and San Salvador effect (San_Sal_ef). The importance of carrying out R\&D activities, cooperation with knowledge agents and the protection of industrial property are framed by the science-push approach as the origin of the processes of knowledge generation and, subsequently, of innovations (Di Stefano, Gambardella, \& Verona, 2012). ${ }^{11}$

In terms of process innovation (proc_innov, column 2), three explanatory variables appear as significant at $1 \%$ significance and with a positive sign: performance of $R \& D$ activities ( $R \& D \_a c t$ ), as in the previous typology; cooperation with agents of the value chain (valuec_co); and cooperation with knowledge agents (know_ag_co). In addition, two variables appear with a 5\% level of significance: use of industrial property (use_IP), with a positive sign, and company size by turnover (sales_12_cat), with a negative sign. In this typology, it is interesting to note the relevance of two types of cooperation, since it indicates that Salvadoran F\&B industry companies have the capacity to interact when innovating in processes with different actors of the sectoral innovation system: clients, suppliers, universities or research centers (Un \& Asakawa, 2015).

As regards organizational innovation (org_innov, column 3), there are three significant variables at $1 \%$ significance, two of which have a positive sign: percentage of university employees the company has (per_emp_uni_cat) and cooperation with value chain agents (valuec_co); while the San Salvador effect (San_Sal_ef) has a negative sign. These results indicate that having qualified personnel positively influences this type of non-technological innovation in Salvadoran F\&B industry firms, which is in line with innovation economics literature (Huerta Arribas et al., 2003). The positive relationship between organizational innovation and establishing links with customers and suppliers is logical, given that organizations must adapt to their business ecosystem in order to survive and generate profits (Pippel, 2014). In contrast, the negative effect associated with urbanization economies indicates that F\&B industry firms outside the capital improve organizational elements to a greater degree, probably to allow them to supply more sophisticated final or intermediate clients.

11 The other approach, the pull of the market (demand pull), can be identified with the increase in variables such as turnover or exports, as well as others which require companies to engage in innovative mechanisms to supply a growing market. 
Finally, with regard to marketing innovation (mark_innov, column 4), two variables are positively linked at $1 \%$ significance: performance of R\&D activities ( $R \& D_{-} a c t$ ) and cooperation with value chain agents (valuec_co). At $5 \%$ significance, two variables appear with a positive sign: percentage of university employees the company has (per_emp_uni_cat), and use of industrial property (use_IP). In addition, with $10 \%$ significance, cooperation with knowledge agents (know_ag_co) shows a positive relationship. Non-technological innovation (org_innov \& mark_innov) shares two variables: presence of university graduates as employees (per_emp_uni_cat), and cooperation with other actors in the value chain (valuec_co); in line with what is posited in innovation economics literature (Pippel, 2014) .

\section{DISCUSSION OF MAIN RESULTS}

When analyzing the innovative behavior of Salvadoran F\&B industry firms, it is possible to identify various determinant innovation factors, which are both internal and external to firms. The results from a multivariate probit model show empirically that these innovation determinants depend on different types of innovation; some are present in various types of innovation, while others affect only one type. Additionally, the model shows how certain types of innovation are intertwined.

In the case of the Salvadoran F\&B industry, it is not possible to identify horizontal determinants that are present in all types of innovation. Three factors are, however, found to be present in three forms of innovation: performance of $R \& D$ activities ( $\left.R \& D_{-} a c t\right)$, use of different types of industrial property (use_IP), and cooperation with value chain agents (valuec_co).

The first two factors are associated with generating and protecting knowledge. These are present with a positive sign in the same three forms of innovation: technological innovations of product and process and marketing innovations. This relationship is consistent with the trend of the positive impact of R\&D activities on national innovation capacity (Furman, Porter, \& Stern, 2002). In the case of firms in developing countries, this generation of knowledge combines efforts to reduce the technological gap with other technologically more advanced countries and to adapt existing knowledge created elsewhere to specific local demand needs. In the case of the F\&B industry, its research needs are not only related to the natural sciences in areas such as biotechnology or nanotechnology applied to new product development, but also to social sciences in terms of knowledge management. In 
this sense, an important part of public financial support for Salvadoran companies is related to acquiring technology through the Productive Development Fund of the Ministry of Economy (Spanish acronym - FONDEPRO) and certain lines of the Salvadoran Development Bank (Spanish acronym - BANDESAL). This financial support is accompanied by actions taken by the General Directorate of Innovation and Competitiveness (Spanish acronym - DGIC) and the El Salvador Technological and Productive Innovation Complex in Agroindustry (Spanish acronym - CITPA). ${ }^{12}$ This government support for the private sector is one example of the relationships among actors in the sectorial innovation system of the Salvadoran F\&B industry. These relationships confirm the existence of this system, although it is still in its early stages.

In addition, the use of industrial property protection mechanisms (use_IP) reflects a growing industry orientation towards an STI approach when innovating, and a higher level of awareness about the need to use this form of protection of research results as a way to ensure adequate profitability is derived from research efforts (Molero Zayas \& Buesa Blanco, 1996). This trend is almost natural for advanced economies, yet for a developing country it reflects how its production apparatus is evolving from an economy based on efficiency to an economy based on innovation (Zhao, 2006). In this sense, since 2009 the National Registry Center (CNR) has increased its activities in an effort to raise industry awareness about the importance of industrial property. In addition, it is important for business associations' public policies and strategies to seek to create synergies that facilitate this type of process for SMEs through aid for the payment of tariffs, or technological and management consulting.

The two previous factors, the presence of $R \& D$ activities ( $R \& D_{-} a c t$ ) and the use of industrial property (use_IP), are also present in marketing innovations, which can be explained by the interaction among R\&D and marketing departments in the new product development process (Olson, Walker, Ruekert, \& Bonner, 2001). This kind of link within firms can generate analytical and symbolic knowledge that can lead to various forms of industrial protection, e.g. industrial designs.

The third variable, which is present in three forms of innovation, is cooperation with value chain agents (valuec_co), which affects innovation in processes, in organization, and in marketing. The link with process innovations occurs in a similar way to what happens for companies in developed countries (Un \& Asakawa, 2015),

12 These two organizations depend on different ministries. The DGIC depends on the Ministry of Economy while the CITPA depends on the Ministry of Education, Science and Technology. 
but not for product innovations (Un et al., 2010). This kind of relationship can be useful for creating technological platforms through the value chain, which enables the needs of a given industrial ecosystem to be met (Gawer, 2014). In this sense, and for the Salvadoran case, the role of large "tractor" firms ${ }^{13}$ in the F\&B industry is paramount since they have a greater capacity to initiate and lead cooperation processes with small and medium enterprises (SMEs) in the F\&B industry. In El Salvador, there are two catalysts for increasing cooperation among companies throughout the value chain. In addition to business associations, such as the El Salvador Chamber of Commerce and Industry (Spanish acronym - CCIES), there is also the Salvadoran association of industrial companies (Spanish acronym - ASI). Both play a major role in promoting sectoral forums for exchanging knowledge and good practices. The government can also act as a facilitator in inter-company dialogue.

The model shows a fourth variable that is related to three types of innovation; cooperation with knowledge agents (know_ag_co), although the level of significance is not the same in the three cases. This variable is linked to technological innovations, as it is found for companies in more advanced countries (Un \& Asakawa, 2015; Un et al., 2010), and with marketing innovation (Pippel, 2014). This type of relationship with universities, public research organizations, technological parks and laboratories is one option for increasing knowledge, which might explain why this variable appears in the same types of innovation as R\&D activities. Moreover, in marketing innovations, these agents can be the source of symbolic knowledge in design and advertising (B.T. Asheim, 2009). In practice, the existence of interface organizations within the scientific system is useful for facilitating collaboration between knowledge generators and companies. In addition, public policies must contribute to cooperative processes that ensure the smooth functioning of the quintuple helix of innovation (Carayannis, Barth, \& Campbell, 2012). In El Salvador, there are several public organizations that engage in activities in this regard: CITPA; DGIC and the National Council of Science and Technology (Spanish acronym - CONACYT). ${ }^{14}$ Once again, the existence of this network of government organizations supporting the performance of innovation activities by the Salvadoran F\&B industry indicates that this is a sectoral system of innovation (Malerba \& Mani, 2009) in its early stages.

13 "Tractor" companies are all the large companies that promote economic growth and development at the macro level, since most are large firms at the national or international level. These represent a fundamental market for the growth and support of small and medium-sized companies (SMEs), which increase their assets and capital through tractor company purchases (Camacho, 2020; Montes Peón, Fernández Muñiz, Gónzalez Fernández, \& Vásquez Ordás, 2015).

14 CONACYT belongs to the Ministry of Education, Science and Technology. 
In addition to the four variables mentioned, there are three factors that are present in two types of innovation: business dimension according to turnover (sales_12_cat), percentage of university employees in the firm (per_emp_uni_cat), and location in the department of San Salvador (San_Sal_ef).

The first variable, company size measured by its sales, is related to technological innovations, with a positive sign for product innovations, as one might expect, but with a negative sign for process innovations. ${ }^{15}$ Hence, for the Salvadoran F\&B industry, a larger size has a positive impact on product innovation, which concurs with what has been pointed out for business generality by Camisón Zornoza et al. (2004), as a larger business size is associated with a greater capacity to take risks as well as with the capacity to carry out R\&D and innovation activities. In contrast, a firm's size is negatively related to process innovation, which can be explained by SMEs' greater flexibility, which in turn allows SMEs to quickly incorporate incremental process innovation (Bhaskaran, 2006). In any case, public innovation policies in El Salvador display a positive bias towards SMEs, with one prominent example being the activities carried out by the Network of Centers for the Development of Micro and Small Enterprises (Spanish acronym - CDMYPEs), promoted by the National Commission of Micro and Small Businesses (Spanish acronym - CONAMYPE), or the services offered by the El Salvador Technological and Productive Innovation Complex in Agroindustry (CITPA).

The second variable, presence of university employees in the company, is linked to organizational and marketing innovations with a positive sign in both cases. In the former case, this positive relationship has already been pointed out for other sectors in Latin American countries such as ICT in Argentina (Moncaut et al., 2017). Therefore, an improvement in the training of those responsible for managing F\&B industry firms or the incorporation of workers with higher educational levels might lead to better performance, especially in the fourth industrial revolution.

The third variable, being located in the department of San Salvador (San_Sal_ef), is linked to urbanization economies and has a positive relationship with product innovation and a negative relationship with organizational innovation. It is reasonable to assume that the existence of a large market and an important accumulation of production resources will generate externalities for F\&B companies, as in low

15 This negative sign also appears if the model is analyzed replacing the variable turnover (sales_12_cat) by other variables, such as employment (emp_12_cat) and size (size). In these two cases, the significance of the contrast is slightly above $10 \%$. 
technology sectors in more developed countries (De Beule \& Van Beveren, 2012). Conversely, the negative effect associated with urbanization economies could be associated with the fact that branches and companies outside the capital need to make organizational innovations in order to adapt their organization in two ways: to adjust global solutions to regional clients or to modify local solutions to national or international clients (Barroso, 2010).

One final factor considered is firm age (age_cat), which is only linked to product innovation with a negative sign. Thus, Salvadoran F\&B industry companies aged less than 10 years old tend to engage in product innovation more than older ones do. This behavior coincides with that of companies from other geographical contexts, where younger businesses are associated with business strategies that include innovation in their competitiveness formula (Do, 2014; Huergo \& Jaumandreu, 2004; Molero Zayas \& Buesa Blanco, 1996). In the Salvadoran case, the greater relative presence of young companies among innovative companies may be influenced by the fact that the impetus for innovation and technological change in El Salvador only became relevant fairly recently; e.g., the Salvadoran Vice-Ministry of Science and Technology was created in 2009.

\section{CONCLUSIONS}

The focus of this paper is to identify which internal and external determinants are relevant to the innovative behavior of F\&B industry firms in El Salvador, an important national low-tech industry in an increasingly globalized economy. The existence of different types of innovation (product, process, marketing, and organizational innovations) advocates using a multivariate probit analysis to take into account the interactions among them. Although the scope of this research is limited, the results might serve as a guide to help Salvadoran F\&B industry firms and entrepreneurs improve their decision-making in innovation issues.

If they are to become competitive in their sectoral system of innovation, Salvadoran F\&B industry firms must undertake R\&D activities and their corresponding industrial protection, especially for technological innovations. Moreover, they can take advantage of their size in order to promote product innovation. Salvadoran firms in the F\&B industry who wish to promote non-technological innovations must be aware of the importance of their workforce's qualifications, e.g. the percentage of employees with university studies. In this sense, it is necessary to combine the 
creation of endogenous postgraduate training skills with the support of government organizations and academia, which implies revising the local educational offer so as to align it as much as possible with the needs of industry and also merge with programs to improve the quality of the outgoing labor force. ${ }^{16}$

Establishing different types of relationships to innovate is paramount; either with knowledge agents, in order to foster technological innovations, or with agents of their value chain, especially when seeking to promote non-technological innovations. Salvadoran companies in the F\&B industry must consider their location wisely, and take advantage of being in the department of San Salvador in order to make product innovations, in some cases, or to promote organizational innovation so as to better interact with their clients, in others. All these previous considerations must take account of the systemic nature of innovation, a business phenomenon where not only the private sector but also the public sector and academia play a key role.

The results of this research might thus prove useful for both the public administration and academia in El Salvador. For the government, the findings might mainly be helpful when designing financial aid and developing infrastructure to support different types of innovation for different kinds of enterprises in the F\&B industry. In this regard, in order to generate product innovation, it is convenient to consider the small size of firms and being located outside San Salvador as a weakness, and the dynamism of young firms as an opportunity. In a similar vein, the public sector must bear in mind the relevance of carrying out $R \& D$ activities, protecting the results and establishing different cooperative relations when innovating among the actors involved in the sectoral innovation system. For the world of academia, there are two main lines of activity: to develop R\&D activities in connection with F\&B industry needs and to improve the provision of education, which must be coordinated with the industrial demands of human capital to innovate.

The previously mentioned public involvement and the participation of nonmarket actors in F\&B industry innovation requires an appropriate "tropicalization" in order to bear the specificities of innovation systems in developing economies and their position in global markets.

16 Aware of the importance of human resources for innovating, in 2012 CONACYT designed an initiative aimed at training at least 75 doctors in science over five years. Unfortunately, this initiative depended on an InterAmerican Development Bank loan and was not ratified by the Salvadoran Legislative Assembly. For its part, the new Salvadoran government that took office in mid-2019 presented its so-called Dalton project through which 20,000 young people are expected to be trained abroad, prioritizing cutting-edge careers, all with the support of international cooperation. 


\section{ACKNOWLEDGMENTS}

The authors are grateful to the anonymous referees of the journal for their useful suggestions to improve the quality of the paper. Usual disclaimers apply.

\section{CONFLICT OF INTEREST STATEMENT}

The authors certify that they have no affiliations with or involvement in any organization or entity with any financial interest or non-financial interest in the subject matter or materials discussed in this manuscript.

\section{REFERENCES}

1. Acosta, M., Coronado, D., \& Romero, C. (2015). Linking public support, R\&D, innovation and productivity: New evidence from the Spanish food industry. Food Policy, 57, 50-61. doi:http://dx.doi.org/10.1016/j.foodpol.2015.09.005

2. Águila Obra, A. R., \& Padilla Meléndez, A. (2010). Factores determinantes de la innovación en empresas de la economía social. La importancia de la formación y la actitud estratégica. CIRIEC-España, Revista de Economía Pública, Social y Cooperativa, 67, 129-155.

3. Almeida, P., \& Phene, A. (2004). Subsidiaries and knowledge creation: The influence of the MNC and host country on innovation. Strategic Management Journal, 25(8-9), 847-864. doi:http://dx.doi.org/10.1002/smj.388

4. Archibugi, D., \& Pianta, M. (1996). Innovation surveys and patents as technology indicators: the state of the art. In OECD (Ed.), Innovation, Patents and Technological Strategies. Paris: OECD.

5. Arocena, R., Göransson, B., \& Sutz, J. (2015). Knowledge policies and universities in developing countries: Inclusive development and the "developmental university". Technology in Society, 41, 10-20. doi:http://doi.org/10.1016/j.techsoc.2014.10.004

6. Arocena, R., \& Sutz, J. (2000). Looking at National Systems of Innovation from the South. Industry and Innovation, 7(1), 55-75. doi:http://dx.doi.org/10.1080/713670247

7. Asheim, B. T. (2009). La política regional de innovación de la próxima generación: cómo combinar los enfoques del impulso por la ciencia y por el usuario en los sistemas regionales de innovación. Ekonomiaz, 70, 86-105.

8. Asheim, B. T., Lars, C., Moodysson, J., \& Jan, V. (2007). Constructing knowledge-based regional advantage: Implications for regional innovation policy. International Journal of Entrepreneurship and Innovation Management, 7(2/3/4/5), 140-155. doi:http://doi. org/10.1504/IJEIM.2007.012879 
9. Barros, H. (2015). Exploring the use of patents in a weak institutional environment: The effects of innovation partnerships, firm ownership, and new management practices. Technovation, 45-46, 63-77. doi:http://dx.doi.org/10.1016/j.technovation.2015.05.003

10. Barroso, H. C. (2010). Culturas regionais e seus impactos na cultura organizacional: representação da matriz e de filiais. São Paulo: Fundação Getúlio Vargas.

11. Bartel, A. P., \& Sicherman, N. (1998). Technological change and the skill acquisition of young workers. Journal of Labor Economics, 16, 718-755. doi:http://dx.doi. org/10.1086/209904

12. Becattini, G. (1990). The Marshallian Industrial District as a Socio-Economic Notion. In F. B. Pyke, G. \& Sengenberger, W. (Ed.), Industrial Districts and Inter-firm Cooperation in Italy (pp. 37-51): International Institute for Labour Studies.

13. Belderbos, R., Carree, M., Diederen, B., Lokshin, B., \& Veugelers, R. (2004). Heterogeneity in $R \& D$ cooperation strategies. International Journal of Industrial Organization, 22 (8-9), 1237-1263. doi:http://dx.doi.org/10.1016/j.jijndorg.2004.08.001

14. Belderbos, R., Carree, M., \& Lokshin, B. (2004). Cooperative R\&D and firm performance. Research Policy, 33(10), 1477-1492. doi:http://dx.doi.org/10.1016/j. respol.2004.07.003

15. Bhargava, M., Chatterjee, R., Grimpe, C., \& Sofka, W. (2011). Marketing Innovation and RED Capabilities - More Than One Way to Innovation Success? . Paper presented at the 3rd European Conference on Corporate R\&D and Innovation CONCORD-2011, Seville.

16. Bhaskaran, S. (2006). Incremental innovation and business performance: Small and medium-size food enterprises in a concentrated industry environment. Journal of Small Business Management, 44, 64-80. doi:http://dx.doi. org/10.1111/j.1540-627X.2006.00154.x

17. Blackburn, R. (2003). Intellectual Property and Innovation Management in Small Firms. New York: Routledge. Taylor \& Francis Group.

18. Calvo, J. (2005). iSon las actividades de I+D una buena aproximación a la innovación tecnológica? Economía Industrial, 358, 173-184.

19. Camacho, J. C. (2020). ¿Qué es una empresa Tractora? Retrieved from http://www. mexicoemprende.org.mx/que-es-una-empresa-tractora

20. Camagni, R. (2005). Economía urbana. Barcelona: Antoni Bosch.

21. Camisón Zornoza, C., Lapiedra Alcamí, R., Segarra Ciprés, M., \& Boronat Navarro, M. (2004). A Meta-analysis of Innovation and Organizational Size. Organization Studies, 25(3), 331-361. doi:http://dx.doi.org/10.1177/0170840604040039

22. Capellari, L., \& Jenkins, S. P. (2003). Multivariate probit regression using simulated maximum likelihood. The Stata Journal, 3(3), 278-294.

23. Carayannis, E. G., Barth, T. D., \& Campbell, D. (2012). The Quintuple Helix innovation model: global warming as a challenge and driver for innovation. New York: Springer.

24. CEPAL. (2017). La Encuesta Nacional de Dinámica de Empleo e Innovación (ENDEI) como herramienta de análisis. La innovación y el empleo en la industria manufacturera 
argentina Santiago de Chile: Comisión Económica para América Latina y el Caribe (CEPAL). División de Publicaciones y Servicios Web.

25. Cohen, W., \& Levinthal, D. (1990). Absorptive Capacity: A New Perspective on Learning and Innovation. Administrative Science Quarterly, 35, 123-133. doi:http:// dx.doi.org/10.2307/2393553

26. Crespi, G., \& Dutrénit, G. (2014). Science, Technology and Innovation Policies for Development. The Latin American Experience. Dordrecht: Springer.

27. Cummings, A. (2007). Against All Odds: building Innovative Capabilities in Rural Economics Initiatives in El Salvador. (Ph. D. ), Aalborg Universitet, Aalborg, Denmark.

28. Cummings, A. (2016). La emergencia de sistemas territoriales de innovación en El Salvador y la participación de las universidades. En J. Núñez Jover \& A. Alcazar Quiñores (Eds.), Universidad y desarrollo local: contribuciones latinoamericanas (pp. 8398). México: Unión de Universidades de América Latina y el Caribe, el Ministerio de Educación Superior de Cuba y la Cátedra Ciencia, Tecnología, Sociedad e Innovación de la Universidad de La Habana.

29. Chen, Y., \& Puttitanun, T. (2005). Intellectual property rights and innovation in developing countries. Journal of Development Economics, 78, 474-493. doi:https://doi. org/10.1016/j.jdeveco.2004.11.005

30. Chesbrough, H. (2003). The Era of Open Innovation. Boston: Harvard Business School Press.

31. Damanpour, F. (1992). Organizational size and innovation. Organization Studies, 13(3), 375-402. doi:http://dx.doi.org/10.1177/017084069201300304

32. Damanpour, F., Walker, R. M., \& Avellaneda, C. N. (2009). Combinative effects of innovation types and organizational Performance: A longitudinal study of service organizations. Journal Of Management Studies, 46(4), 650-675. doi:http://dx.doi. org/10.1111/j.1467-6486.2008.00814.x

33. De Beule, F., \& Van Beveren, I. (2012). Does firm agglomeration drive product innovation and renewal? An application for Belgium. Tijdschrift voor Economische en Sociale Geografie, 103(4), 457-472. doi:http://dx.doi.org/10.1111/j.1467-9663.2012.00715.x

34. De Fuentes, C., Dutrénit, G., Santiago, F., \& Gras, N. (2015). Determinants of Innovation and Productivity in the Service Sector in Mexico. Emerging Markets Finance and Trade, 51(3), 578-592. doi:http://doi.org/10.1080/1540496X.2015.1026693

35. Di Stefano, G., Gambardella, A., \& Verona, G. (2012). Technology push and demand pull perspectives in innovation studies: Current findings and future research directions. Research Policy, 41 (8), 1283-1295. doi:http://dx.doi.org/10.1016/j.respol.2012.03.021

36. Dirección General de Estadística y Censos. (2012). Directorio de unidades económicas 2011-2012. San Salvador: DIGESTYC.

37. Do, T. H. (2014). Determinants of innovation commercialization management and anticipated returns: An exploratory typology of SMEs. International Journal of Innovation and Technology Management, 11, 1450042-1450041-1450020. doi:http:// dx.doi.org/10.1142/S0219877014500424 
38. Dosi, G. (1988). Sources, Procedures and Microeconomics Effects of Innovation. Journal of Economic Literature, 26, 1120-1171.

39. Dosi, G., \& Malerba, F. (1996). Organization and Strategy in the Evolution of the Enterprise. London: Macmillan

40. Duranton, G. (2014). Growing Through Cities in Developing Countries. World Bank Research Observer, Policy Working Paper No. 6818.

41. Dutrénit, G., \& Sutz, J. (2014). National Innovation Systems, Social Inclusion And Development. The Latin American Experience. Northampton, Massachusetts: Edward Elgar.

42. Fundación COTEC. (2009). Libro blanco de la innovación en la Comunidad de la Rioja. Madrid: Fundación COTEC.

43. Furman, J. L., Porter, M., \& Stern, S. (2002). The Determinants of National Innovative Capacity. Research Policy, 31, 899-933. doi: http://dx.doi.org/10.1016/ S0048-7333(01)00152-4

44. Galende, J., \& Fuente, J. M. (2003). Internal factors determining a firm's innovation behaviour. Research Policy, 32, 715-736. doi:http://doi.org/10.1016/ S0048-7333(02)00082-3

45. Gawer, A. (2014). Bridging differing perspectives on technological platforms: Toward an integrative framework. Research Policy, 43, 1239-1249. doi:http://dx.doi.org/10.1016/j. respol.2014.03.006

46. Gobierno de El Salvador. (2011). Política Industrial 2011-2024. San Salvador: Secretaria Técnica de la Presidencia.

47. Gobierno de El Salvador. (2012). Política Nacional de Innovación, Ciencia y Tecnología. San Salvador: Secretaría Técnica de la Presidencia, Ministerio de Economía y Ministerio de Educación.

48. Griffith, R., Redding, S., \& Van Reenen, J. (2003). R\&D and Absorptive Capacity: Theory and Empirical Evidence. Scandinavian Journal of Economics, 105(1), 99-118. doi:http://doi.org/10.1111/1467-9442.00007

49. Gu, S., Adeoti, J., Castro, A., Orozco, J., \& Díaz, R. (2012). The agro-food sector in catching up countries: a comparative study of four cases. In F. Malerba \& R. Nelson (Eds.), Economic Development as a Learning Process. Variation across Sectoral Systems. Cheltenham: Edward Elgar.

50. Hadjimanolis, A. (2000). A Resource-based View of Innovativeness in Small Firms. Technology Analysis and Strategic Management, 12, 263-281. doi:http://dx.doi. org/10.1080/713698465

51. Hoselitz, B. F. (1954). Industrial Development of El Salvador. Washington D.C.: Catholic University of America.

52. Huergo, E., \& Jaumandreu, J. (2004). How does probability of innovation change with firm age? Small Business Economics, 22, 193-207. doi:http://dx.doi.org/10.1023/ B:SBEJ.0000022220.07366.b5 
53. Huerta Arribas, E., Bayo Moriones, J. A., García Olaverri, C., \& Merino Díaz de Cerio, J. (2003). Los desafíos de la competitividad: la innovación organizativa y tecnología en la empresa española. Bilbao: Fundación BBVA.

54. Jensen, M. B., Johnson, B., Lorenz, E., \& Lundvall, B. Å. (2007). Forms of knowledge and modes of innovation. Research Policy, 36, 680-693. doi:http://dx.doi.org/10.1016/j. respol.2007.01.006

55. Malerba, F. (2002). Sectoral Systems of Innovation and Production. Research Policy, 31, 247-264. doi:http://dx.doi.org/10.1016/S0048-7333(01)00139-1

56. Malerba, F. (2004). Sectoral Systems of Innovation: Concepts, Issues and analyses of Six Major Sectors in Europe. Cambridge: Cambridge University Press.

57. Malerba, F., \& Mani, S. (2009). Sectoral Systems of Innovation and Production in Developing Countries. Cheltenham: Edward Elgar.

58. Ministerio de Economía de El Salvador. (2014). Política Nacional de Fomento, Diversificación y Transformación Productiva de El Salvador. San Salvador: Ministerio de Economía

59. Molero Zayas, J., \& Buesa Blanco, M. (1996). Patterns of technological change among Spanish innovative firms: the case of the Madrid region. Research Policy, 25, 647-663. doi:http://dx.doi.org/10.1016/0048-7333(95)00873-X

60. Moncaut, N., Robert, V., \& Yoguel, G. (2017). El rol de las capacidades en la relación entre difusión de las TIC y productividad en empresas manufactureras argentinas. Una revisión de la hipótesis de complementariedad. En CEPAL (Ed.), La Encuesta Nacional de Dinámica de Empleo e Innovación (ENDEI) como herramienta de análisis. La innovación y el empleo en la industria manufacturera argentina (pp. 97-115). Santiago de Chile: Comisión Económica para América Latina y el Caribe (CEPAL). División de Publicaciones y Servicios Web.

61. Montes Peón, J. M., Fernández Muñiz, B., Gónzalez Fernández, L. I., \& Vásquez Ordás, C. J. (2015). Estudio de Investigación sobre las Empresas Tractoras de Asturias. Oviedo, Principado de Asturias: Instituto de Desarrollo Económico del Principado de Asturias (IDEPA).

62. Nassimbeni, G. (2001). Technology, innovation capacity, and the export attitude of small manufacturing firms: A logit/tobit model. Research policy, 30, 245-262. doi:http:// dx.doi.org/10.1016/S0048-7333(99)00114-6

63. Nelson, R. R. (1993). National Systems of Innovation: A Comparative analysis. Oxford: Oxford University Press.

64. Nelson, R. R., \& Winter, S. G. (1982). An Evolutionary Theory of Economic Change. Cambridge, Massachusetts: Harvard University Press.

65. OCDE. (2005). Manual de Oslo: Guía para la recogida e interpretación de datos sobre innovación. París: OCDE.

66. Olson, E. M., Walker, O. C., Ruekert, R. W., \& Bonner, J. M. (2001). Patterns of cooperation during new product development among marketing, operations and R\&D: Implications for project performance. Journal of Product Innovation Management, 18, 258-271. doi:http://dx.doi.org/10.1016/S0737-6782(01)00091-1 
67. Orozco-Barrantes, J., \& Barboza-Arias, L. M. (2018). Innovación y crecimiento inclusivo en Costa Rica: el caso del sector lácteo. Revista de Política Económica y Desarrollo Sostenible, 4(1), 1-20. doi:http://dx.doi.org/10.15359/peds.4-1.2

68. Orozco, J. (2014). Institutional innovation and inclusive growth: lessons from the coffee and palm oil sectors in Costa Rica. In G. Dutrénit \& J. Sutz (Eds.), National Innovation Systems, Social Inclusion And Development. The Latin American Experience. Northampton, Massachusetts: Edward Elgar.

69. Padilla Pérez, R. (2013). Sistemas de innovación en Centroamérica. Fortalecimiento a través de la integración regional. Santiago de Chile: Comisión Económica para América Latina y el Caribe (CEPAL).

70. Pavitt, K. (1984). Sectoral Patterns of Technical Change: Towards a Taxonomy and a Theory. Research Policy, 13, 343-373. doi:http://dx.doi. org/10.1016/0048-7333(84)90018-0

71. Peraza Castaneda, E., Gómez García, J., \& Aleixandre Mendizábal, G. (2016). Los factores determinantes del comportamiento innovador de las cooperativas: un análisis para el caso de Castilla y León. Revista de Estudios Cooperativos 122, 252-284. doi:http:// dx.doi.org/10.5209/rev_REVE.2016.v122.52025

72. Pessoa de Matos, M. G., Borin, E., Cassiolato, J. E., de Arruda, D. R., \& Sanchez Marcellino, I. (2016). La evolución de los arreglos productivos locales en una década. En J. Núñez Jover \& A. Alcazar Quiñores (Eds.), Universidad y desarrollo local: contribuciones latinoamericanas (pp. 33-52). México: Unión de Universidades de América Latina y el Caribe, el Ministerio de Educación Superior de Cuba y la Cátedra Ciencia, Tecnología, Sociedad e Innovación de la Universidad de La Habana.

73. Pippel, G. (2014). R\&D cooperation for non-technological innovations. Economics of Innovation and New Technology, 23, 611-630. doi:http://dx.doi.org/10.1080/10438 599.2013.871167

74. Polése, M. (1998). Economía Urbana y Regional. Introducción a la relación entre territorio y desarrollo. Cartago, Costa Rica: Editoriales Universitarias de América Latina y el Caribe (EULAC) y la Agencia de Cooperación Técnica Alemana (GTZ).

75. Rama, R. (2008). Handbook of innovation in the food and drink industry. New York, United States of America: The Haworth Press. Taylor \& Francis Group.

76. Ruiz López, S., \& Colin Salgado, M. (2010). Innovación, propiedad intelectual y competitividad. La denominación de origen como estrategia de competitividad para la industria del calzado de León, Guanajuato. Revista Científica Teorías, Enfoques y Aplicaciones en las Ciencias Sociales, 4, 33-44.

77. Soluri, J. (2009). Banana Cultures: Agriculture, Consumption, and Environmental Change in Honduras and the United States. Austin, Texas, United States of America.: University of Texas Press.

78. Suárez, D., Yoguel, G., Robert, V., \& Barletta, F. (2014). The Argentinean System of Innovation: Micro Determinants and Meso- Macro Disarticulation. In G. Dutrénit \& J. Sutz (Eds.), National Innovation Systemas, Social Inclusion and Development. The Latin American Experience (pp. 102-132). Cheltenham, UK: Edward Elgar Publishing Ltd. 
Elías Humberto Peraza Castaneda • Guillermo Aleixandre Mendizábal

79. Tolentino, P. E. (1993). Technological innovation and Third World multinationals. London: Routledge.

80. Un, C. A., \& Asakawa, K. (2015). Types of R\&D collaborations and process innovation: The benefit of collaborating upstream in the knowledge chain. Journal of Product Innovation Management, 32, 138-153. doi:http://dx.doi.org/10.1111/jpim.12229

81. Un, C. A., Cuervo-Cazurra, A., \& Asakawa, K. (2010). R\&D Collaborations and Product Innovation. Journal of Product Innovation Management, 27, 673-689. doi:http:// dx.doi.org/10.1111/j.1540-5885.2010.00744.x

82. Vega Jurado, J., Gutiérrez Gracia, A., Fernández de Lucio, I., \& Manjarrés Henríquez, L. (2008). The effect of external and internal factors on firms' product innovation. Research Policy, 37, 616-632. doi:http://dx.doi.org/10.1016/j.respol.2008.01.001

83. Viceministerio de Comercio e Industria. (2013). Encuesta Nacional de Innovación 2013-Capítulo Industrial. San Salvador.

84. Wakelin, K. (1998). Innovation and export behaviour at the firm level. Research Policy, 26, 829-841. doi:http://dx.doi.org/10.1016/S0048-7333(97)00051-6

85. Zhao, M. (2006). Conducting $R \& D$ in countries with weak intellectual property rights protection. Management Science, 52, 1185-1199. 


\section{APPENDIX}

Appendix 1.

\section{Bivariate analysis of internal determinants for innovating in Salvadoran F\&B industry firms}

\begin{tabular}{|c|c|c|c|c|c|c|c|c|c|}
\hline \multirow{2}{*}{ Variable } & \multirow{2}{*}{$\begin{array}{l}\text { Segmentation } \\
\text { criterion }\end{array}$} & \multicolumn{2}{|c|}{$\begin{array}{c}\text { Product } \\
\text { innovation (1) }\end{array}$} & \multicolumn{2}{|c|}{$\begin{array}{c}\text { Process } \\
\text { innovation (2) }\end{array}$} & \multicolumn{2}{|c|}{$\begin{array}{l}\text { Organizational } \\
\text { innovation (3) }\end{array}$} & \multicolumn{2}{|c|}{$\begin{array}{c}\text { Marketing } \\
\text { innovation (4) }\end{array}$} \\
\hline & & $\begin{array}{l}\% \\
\text { Yes }\end{array}$ & $\begin{array}{c}\text { Sig. } \chi^{2} \\
\text { Pearson }\end{array}$ & $\begin{array}{c}\% \\
\text { Yes }\end{array}$ & $\begin{array}{c}\text { Sig. } \chi^{2} \\
\text { Pearson }\end{array}$ & & $\begin{array}{c}\text { Sig. } \chi^{2} \\
\text { Pearson }\end{array}$ & $\begin{array}{c}\% \\
\text { Yes }\end{array}$ & $\begin{array}{c}\text { Sig. } \chi^{2} \\
\text { Pearson }\end{array}$ \\
\hline \multirow{4}{*}{$\begin{array}{c}\text { Size } \\
\mathrm{nT}=378\end{array}$} & Small & $20.6 \%$ & \multirow{4}{*}{$0.017^{* *}$} & $20.5 \%$ & \multirow{4}{*}{0.277} & $12.3 \%$ & \multirow{4}{*}{$0.077^{*}$} & $10.9 \%$ & \multirow{4}{*}{$0.000^{* * *}$} \\
\hline & {$[\mathrm{n} 0=267]$} & & & & & & & & \\
\hline & Med./Big & $32.4 \%$ & & $26.1 \%$ & & $19.8 \%$ & & $29.7 \%$ & \\
\hline & {$[\mathrm{n} 1=111]$} & & & & & & & & \\
\hline \multirow{4}{*}{$\begin{array}{c}\text { Sales } \\
\mathrm{nT}=379\end{array}$} & $\leq 1,000,000 \$$ & $15.9 \%$ & \multirow{4}{*}{$0.000^{* * *}$} & $22.4 \%$ & \multirow{4}{*}{0.900} & $12.1 \%$ & \multirow{4}{*}{0.101} & $11.6 \%$ & \multirow{4}{*}{$0.002^{* * *}$} \\
\hline & {$[\mathrm{n} 0=232]$} & & & & & & & & \\
\hline & $>1,000,000 \$$ & $37.4 \%$ & & $21.8 \%$ & & $18.4 \%$ & & $24.5 \%$ & \\
\hline & {$[\mathrm{n} 1=147]$} & & & & & & & & \\
\hline \multirow{4}{*}{$\begin{array}{c}\text { Employment } \\
\mathrm{nT}=379\end{array}$} & $\leq 50 \mathrm{emp}$ & $16.1 \%$ & \multirow{4}{*}{$0.000^{* * *}$} & $20.0 \%$ & \multirow{4}{*}{0.150} & $12.9 \%$ & \multirow{4}{*}{0.217} & $10.2 \%$ & \multirow{4}{*}{$0.000^{* * *}$} \\
\hline & {$[\mathrm{n} 0=255]$} & & & & & & & & \\
\hline & $>50 \mathrm{emp}$ & $41.1 \%$ & & $26.6 \%$ & & $17.7 \%$ & & $29.8 \%$ & \\
\hline & {$[\mathrm{n} 1=124]$} & & & & & & & & \\
\hline \multirow{4}{*}{$\begin{array}{c}\% \text { university } \\
\text { graduate employees } \\
\mathrm{nT}=379\end{array}$} & $\leq 5 \%$ & $21.4 \%$ & \multirow{4}{*}{0.277} & $19.0 \%$ & \multirow{4}{*}{0.258} & $10.1 \%$ & \multirow{4}{*}{$0.039 * *$} & $11.9 \%$ & \multirow{4}{*}{$0.050^{* *}$} \\
\hline & {$[\mathrm{n} 0=159]$} & & & & & & & & \\
\hline & $>5 \%$ & $26.4 \%$ & & $24.2 \%$ & & $17.8 \%$ & & $19.6 \%$ & \\
\hline & {$[\mathrm{n} 1=220]$} & & & & & & & & \\
\hline \multirow{4}{*}{$\begin{array}{c}\text { Exports over } \\
\text { sales } \\
\mathrm{nT}=379\end{array}$} & No & $21.0 \%$ & & $19.6 \%$ & & $15.7 \%$ & & $15.6 \%$ & \\
\hline & {$[\mathrm{n} 0=281]$} & & $0014 * *$ & & $0048 *$ & & 0321 & & 0431 \\
\hline & $\mathrm{Si}$ & $33.7 \%$ & 0.014 & $29.6 \%$ & 0.048 & $11.2 \%$ & 0.321 & $19.4 \%$ & 0.431 \\
\hline & {$[\mathrm{n} 1=98]$} & & & & & & & & \\
\hline & $\leq 10$ years & $38.6 \%$ & & $21.1 \%$ & & $8.6 \%$ & & $16.9 \%$ & \\
\hline Firm age & {$[\mathrm{n} 0=70]$} & & 000 & & 0875 & & 01 & & 1000 \\
\hline $\mathrm{nT}=378$ & $>10$ year & $20.8 \%$ & 0.003 & $22.4 \%$ & $0.8 / 5$ & $15.9 \%$ & 0.135 & $16.6 \%$ & 1.000 \\
\hline & {$[\mathrm{n} 1=308]$} & & & & & & & & \\
\hline & No & $13.4 \%$ & & $15.2 \%$ & & $12.1 \%$ & & $10.7 \%$ & \\
\hline R\&D activities & {$[\mathrm{n} 0=290]$} & & $=0.000 * * *$ & & $0,000 * * *$ & & $0.024^{* *}$ & & $0.000 * * *$ \\
\hline $\mathrm{nT}=379$ & Yes & $59.6 \%$ & $0.000^{2}$ & $43.8 \%$ & 0.000 & $22.5 \%$ & 0.024 & $35.6 \%$ & \\
\hline & {$[\mathrm{n} 1=89]$} & & & & & & & & \\
\hline Use of patents, & No & $19.6 \%$ & & $19.8 \%$ & & $13.6 \%$ & & $14.2 \%$ & \\
\hline utility models and & {$[\mathrm{n} 0=352]$} & & $0,000 * * *$ & & 00 & & $0080 *$ & & $0 \cap 0 \cap * * *$ \\
\hline industrial design & Yes & $84.6 \%$ & -0.000 & $53.8 \%$ & 0.000 & $26.9 \%$ & 0.080 & $48.0 \%$ & 0.000 \\
\hline $\mathrm{nT}=378$ & {$[\mathrm{n} 1=26]$} & & & & & & & & \\
\hline
\end{tabular}


Elías Humberto Peraza Castaneda • Guillermo Aleixandre Mendizábal

\begin{tabular}{|c|c|c|c|c|c|c|c|c|c|}
\hline \multirow{2}{*}{ Variable } & \multirow{2}{*}{$\begin{array}{l}\text { Segmentation } \\
\text { criterion }\end{array}$} & \multicolumn{2}{|c|}{$\begin{array}{c}\text { Product } \\
\text { innovation (1) }\end{array}$} & \multicolumn{2}{|c|}{$\begin{array}{c}\text { Process } \\
\text { innovation (2) }\end{array}$} & \multicolumn{2}{|c|}{$\begin{array}{l}\text { Organizational } \\
\text { innovation (3) }\end{array}$} & \multicolumn{2}{|c|}{$\begin{array}{c}\text { Marketing } \\
\text { innovation (4) }\end{array}$} \\
\hline & & $\begin{array}{c}\% \\
\text { Yes }\end{array}$ & $\begin{array}{c}\text { Sig. } \chi^{2} \\
\text { Pearson }\end{array}$ & $\begin{array}{c}\% \\
\text { Yes }\end{array}$ & $\begin{array}{c}\text { Sig. } \chi^{2} \\
\text { Pearson }\end{array}$ & & $\begin{array}{c}\text { Sig. } \chi^{2} \\
\text { Pearson }\end{array}$ & $\begin{array}{c}\% \\
\text { Yes }\end{array}$ & $\begin{array}{c}\text { Sig. } \chi^{2} \\
\text { Pearson }\end{array}$ \\
\hline \multirow{4}{*}{$\begin{array}{c}\text { Use of trademark and } \\
\text { orig. appellation } \mathrm{nT} \\
\quad=378\end{array}$} & No & \multirow[t]{2}{*}{$10.3 \%$} & \multirow{4}{*}{$0.000^{* * *}$} & $17.7 \%$ & \multirow{4}{*}{$0.000^{* * *}$} & $12.2 \%$ & \multirow{4}{*}{$0.012^{* *}$} & $12.2 \%$ & \multirow{4}{*}{0.000} \\
\hline & {$[\mathrm{n} 0=311]$} & & & & & & & & \\
\hline & Yes & \multirow[t]{2}{*}{$88.2 \%$} & & $42.6 \%$ & & $25.0 \%$ & & $35.8 \%$ & \\
\hline & {$[\mathrm{n} 1=68]$} & & & & & & & & \\
\hline \multirow{4}{*}{$\begin{array}{l}\text { Foreign Capital } \\
\qquad \mathrm{nT}=379\end{array}$} & No & \multirow[t]{2}{*}{$22.5 \%$} & \multirow{4}{*}{$0.010^{* * *}$} & $21.9 \%$ & \multirow{4}{*}{1.000} & $14.5 \%$ & \multirow{4}{*}{1.000} & $16.2 \%$ & \multirow{4}{*}{0.787} \\
\hline & {$[\mathrm{n} 0=351]$} & & & & & & & & \\
\hline & Yes & \multirow[t]{2}{*}{$46.4 \%$} & & $22.2 \%$ & & $14.3 \%$ & & $18.5 \%$ & \\
\hline & [n1= 28] & & & & & & & & \\
\hline \multirow{4}{*}{$\begin{array}{c}\text { Information from } \\
\text { internal source } \\
\mathrm{nT}=379\end{array}$} & No & \multirow[t]{2}{*}{$11.3 \%$} & \multirow{4}{*}{$0.000^{* * *}$} & $7.7 \%$ & \multirow{4}{*}{$0.000^{* * *}$} & $11.3 \%$ & \multirow{4}{*}{$0.021^{* *}$} & $5.7 \%$ & \multirow{4}{*}{0.000} \\
\hline & {$[\mathrm{n} 0=247]$} & & & & & & & & \\
\hline & Yes & \multirow[t]{2}{*}{$48.5 \%$} & & $49.2 \%$ & & $20.5 \%$ & & $37.1 \%$ & \\
\hline & {$[\mathrm{n} 1=132]$} & & & & & & & & \\
\hline & No & $16.1 \%$ & & $12.0 \%$ & & $12.0 \%$ & & $8.8 \%$ & \\
\hline $\begin{array}{l}\text { Values chain as } \\
\text { source of information }\end{array}$ & {$[\mathrm{n} 0=274]$} & & $0000 * * *$ & & $0 \cap 0 \Omega 0 * * *$ & & $0033 * *$ & & $\cap \cap \cap 0$ **** \\
\hline $\mathrm{nT}=379$ & Yes & $45.7 \%$ & & $48.6 \%$ & 0.000 & $21.2 \%$ & 0.035 & $36.5 \%$ & 0.000 \\
\hline & [n1=105] & & & & & & & & \\
\hline Knowledge & No & $22.4 \%$ & & $18.0 \%$ & & $12.7 \%$ & & $13.0 \%$ & \\
\hline agents as source of & {$[\mathrm{n} 0=322]$} & & ००१९२* & & $0 \cap 0 \Omega *$ & & 00 & & $\cap \cap 0 \cap * * *$ \\
\hline information & Yes & $33.3 \%$ & (0.0 & $45.6 \%$ & 0.000 & $24.6 \%$ & $0.02 \mathrm{~J}$ & $36.8 \%$ & 0.000 \\
\hline & {$[\mathrm{n} 1=57]$} & & & & & & & & \\
\hline & No & $23.0 \%$ & & $21.1 \%$ & & $14.4 \%$ & & $16.6 \%$ & \\
\hline Cooperation within & {$[\mathrm{n} 0=361]$} & & $0020 * *$ & & $0036 * *$ & & 0734 & & $10 \Omega 0$ \\
\hline $\mathrm{nT}=379$ & Yes & $50.0 \%$ & $0.0<0$ & $44.4 \%$ & 0.050 & $16.7 \%$ & 0.134 & $16.7 \%$ & 1.000 \\
\hline & [n1= 18] & & & & & & & & \\
\hline & No & $17.2 \%$ & & $15.3 \%$ & & $9.3 \%$ & & $10.4 \%$ & \\
\hline Value chain & {$[\mathrm{n}=268]$} & & 001 & & - & & 00 & & 0 \\
\hline $\mathrm{nT}=379$ & Yes & $41.4 \%$ & 0.000 & $38.7 \%$ & 0.000 & $27.3 \%$ & 0.000 & $30.9 \%$ & 0.000 \\
\hline & {$[\mathrm{n} 1=111]$} & & & & & & & & \\
\hline & No & $22.1 \%$ & & $19.8 \%$ & & $14.0 \%$ & & $14.8 \%$ & \\
\hline Knowledge agent & {$[\mathrm{n} 0=358]$} & & 000 & & $0 \Omega 0$ & & 0189 & & $0 \cap 02$ *** \\
\hline $\mathrm{nT}=379$ & Yes & $61.9 \%$ & 0.000 & $61.9 \%$ & 0.000 & $25.0 \%$ & 0.109 & $45.0 \%$ & 0.002 \\
\hline & {$[\mathrm{n} 1=21]$} & & & & & & & & \\
\hline
\end{tabular}

Note: ${ }^{* *}$ significant at $1 \%$; ** significant at $5 \%$; $^{*}$ significant at $10 \%$

Source: Author's calculations. 
Appendix 2.

Bivariate analysis of external determinants for innovating in Salvadoran F\&B industry firms

\begin{tabular}{|c|c|c|c|c|c|c|c|c|c|}
\hline \multirow{2}{*}{ Variable } & \multirow{2}{*}{$\begin{array}{l}\text { Segmenta-tion } \\
\text { criterion }\end{array}$} & \multicolumn{2}{|c|}{$\begin{array}{c}\text { Product } \\
\text { innovation (1) }\end{array}$} & \multicolumn{2}{|c|}{$\begin{array}{c}\text { Process } \\
\text { innovation (2) }\end{array}$} & \multicolumn{2}{|c|}{$\begin{array}{l}\text { Organizational } \\
\text { innovation (3) }\end{array}$} & \multicolumn{2}{|c|}{$\begin{array}{c}\text { Marketing } \\
\text { innovation (4) }\end{array}$} \\
\hline & & $\begin{array}{c}\% \\
\text { Yes }\end{array}$ & $\begin{array}{l}\text { Sig. } \chi^{2} \\
\text { Pearson }\end{array}$ & $\begin{array}{c}\% \\
\text { Yes }\end{array}$ & $\begin{array}{l}\text { Sig. } \chi^{2} \\
\text { Pearson }\end{array}$ & $\begin{array}{c}\% \\
\text { Yes }\end{array}$ & $\begin{array}{c}\text { Sig. } \chi^{2} \\
\text { Pearson }\end{array}$ & $\begin{array}{c}\% \\
\text { Yes }\end{array}$ & A \\
\hline \multirow{4}{*}{$\begin{array}{c}\text { San Salvador } \\
\mathrm{nT}=379\end{array}$} & Yes & $18.5 \%$ & \multirow{4}{*}{$0.012^{* *}$} & $20.1 \%$ & \multirow{4}{*}{0.456} & $212 \%$ & \multirow{4}{*}{$0.000^{* * *}$} & $16.3 \%$ & \multirow{4}{*}{1.000} \\
\hline & [n $0=184]$ & $10.5 \%$ & & & & $21.2 \%$ & & & \\
\hline & No & 2070 & & $23.7 \%$ & & $820 \%$ & & 1650 & \\
\hline & [n1=195] & $29.1 \%$ & & & & $8 . \angle \%$ & & $10.5 \%$ & \\
\hline \multirow{4}{*}{$\begin{array}{c}\text { Population } \\
\text { density } 2012 \\
\text { nT }=379\end{array}$} & $\leq 297 \mathrm{~h} / \mathrm{km} 2$ & 2000 & \multirow{4}{*}{0.297} & $21.3 \%$ & \multirow{4}{*}{1.000} & $200 \%$ & \multirow{4}{*}{$0.002^{* * *}$} & 1470 & \multirow{4}{*}{0.730} \\
\hline & {$[\mathrm{n} 0=76]$} & $20.9 \%$ & & & & $3.9 \%$ & & $14.1 \%$ & \\
\hline & $>297$ h/km2 & $231 \%$ & & $22.1 \%$ & & $172 \%$ & & $168 \%$ & \\
\hline & {$[\mathrm{n} 1=303]$} & $23.1 \%$ & & & & $17.2 \%$ & & $16.8 \%$ & \\
\hline \multirow{4}{*}{$\begin{array}{c}\text { Annual growth } \\
\text { of population. } \\
2007-2012 \\
\text { nT }=379\end{array}$} & $\leq 1.7 \%$ & 3230 & \multirow{4}{*}{$0.100^{*}$} & $27.1 \%$ & \multirow{4}{*}{0.308} & $670 \%$ & \multirow{4}{*}{$0.071^{*}$} & $186 \%$ & \multirow{4}{*}{0.572} \\
\hline & {$[\mathrm{n} 0=60]$} & $33.3 \%$ & & & & $0.1 \%$ & & $18.6 \%$ & \\
\hline & $>1.7 \%$ & $2260 \%$ & & $21.1 \%$ & & $160 \%$ & & $160 \%$ & \\
\hline & {$[\mathrm{n} 1=319]$} & $22.6 \%$ & & & & $16.0 \%$ & & $10.0 \%$ & \\
\hline \multirow{4}{*}{$\begin{array}{c}\text { Business } \\
\text { density. } 2012 \\
\mathrm{nT}=378\end{array}$} & $\leq 7.7$ & 2810 & \multirow{4}{*}{0.501} & $24.1 \%$ & \multirow{4}{*}{0.732} & $520 \%$ & \multirow{4}{*}{$0.026^{* *}$} & 1930 & \multirow{4}{*}{0.560} \\
\hline & {$[\mathrm{n} 0=57]$} & $20.1 \%$ & & & & $3.2 \%$ & & $19.3 \%$ & \\
\hline & $>7.7$ & 2240 & & $21.8 \%$ & & 1620 & & $150 \%$ & \\
\hline & {$[\mathrm{n} 1=321]$} & $23.4 \%$ & & & & $16.2 \%$ & & $15.9 \%$ & \\
\hline \multirow{4}{*}{$\begin{array}{c}\text { Annual growth } \\
\text { of employment. } \\
2007-2012 \\
\text { nT }=379\end{array}$} & $\leq 3.32 \%$ & $2140 \%$ & \multirow{4}{*}{$0.078^{*}$} & $20.6 \%$ & \multirow{4}{*}{0.302} & $181 \%$ & & $181 \%$ & \\
\hline & {$[\mathrm{n} 0=248]$} & $21.4 \%$ & & & & $18.1 \%$ & คคคЯะ*** & $18.1 \%$ & 0211 \\
\hline & $>3.32 \%$ & 2900 & & $25.2 \%$ & & $760 \%$ & 0.000 & $1270 \%$ & 0.311 \\
\hline & {$[\mathrm{n} 1=131]$} & $29.8 \%$ & & & & $1.6 \%$ & & $13.1 \%$ & \\
\hline$\%$ industrial & $\leq 15.9 \%$ & 3120 & & $27.9 \%$ & & $600 \%$ & & $1940 \%$ & \\
\hline employment. & {$[\mathrm{n} 0=67]$} & $31.3 \%$ & 0155 & & (202 & $0.0 \%$ & $0034 * *$ & $19.4 \%$ & 0475 \\
\hline 2012 & $>15.9 \%$ & $225 \%$ & 0.155 & $20.9 \%$ & 0.202 & $163 \%$ & 0.034 & $160 \%$ & $0.4 / 5$ \\
\hline $\mathrm{nT}=378$ & {$[\mathrm{n} 1=311]$} & & & & & $16.3 \%$ & & $16.0 \%$ & \\
\hline Annual growth & $\leq 16.5 \%$ & $298 \%$ & & $23.0 \%$ & & 70 & & 1610 & \\
\hline of industrial & [n0=161] & $29.8 \%$ & & & & $8.1 \%$ & & $16.1 \%$ & \\
\hline $\begin{array}{c}\text { employment. } \\
2007-2012\end{array}$ & $>16.5 \%$ & $202 \%$ & $0.039^{* *}$ & $21.7 \%$ & 0.803 & $188 \%$ & 0.007 & $170 \%$ & 0.889 \\
\hline $\mathrm{nT}=379$ & [n1=218 ] & $20.2 \%$ & & & & $18.8 \%$ & & $1 / .0 \%$ & \\
\hline
\end{tabular}

Note: *** significant at $1 \%$; ** significant at $5 \%$; ${ }^{*}$ significant at $10 \%$

Source: Author's calculations. 
Elías Humberto Peraza Castaneda • Guillermo Aleixandre Mendizábal

Appendix 3.

Individual probit models on innovation in the F\&B industry in El Salvador

\begin{tabular}{|c|c|c|c|c|c|c|c|c|}
\hline \multirow{2}{*}{ variables } & \multicolumn{2}{|c|}{ prod_innov } & \multicolumn{2}{c|}{ proc_innov } & \multicolumn{2}{c|}{ org_innov } & \multicolumn{2}{c|}{ mark_innov } \\
\cline { 2 - 10 } & \multicolumn{2}{|c|}{$(1)$} & \multicolumn{2}{|c|}{$(2)$} & \multicolumn{2}{c|}{$(3)$} & \multicolumn{2}{c|}{$(4)$} \\
\cline { 2 - 10 } & Value & Sig. & Value & Sig. & Value & Sig. & Value & Sig. \\
\hline sales_12_cat & 0.485 & $* * *$ & -0.426 & $* *$ & 0.048 & & 0.272 & \\
\hline per_emp_uni_cat & 0.006 & & 0.186 & & 0.452 & $* *$ & 0.317 & $*$ \\
\hline age_cat & -0.636 & $* * *$ & 0.210 & & 0.391 & & 0.061 & \\
\hline R\&D_act & 1.074 & $* * *$ & 0.698 & $* * *$ & 0.150 & & 0.500 & $* * *$ \\
\hline use_IP & 1.837 & $* * *$ & 0.604 & $* *$ & 0.129 & & 0.701 & $* *$ \\
\hline valuec_co & 0.273 & & 0.627 & $* * *$ & 0.710 & $* * *$ & 0.494 & $* * *$ \\
\hline know_ag_ac & 0.800 & $* *$ & 0.890 & $* * *$ & 0.402 & & 0.647 & $* *$ \\
\hline San_Sal_ef & 0.480 & $* * *$ & 0.090 & & -0.693 & $* * *$ & 0.015 & $*$ \\
\hline _cons & -1.332 & $* * *$ & -1.476 & $* * *$ & -1.746 & $* * *$ & -1.807 & $* * *$ \\
\hline pseudo R-sq & 0.335 & & 0.161 & & 0.143 & & 0.159 & \\
\hline Pearson chi2(47) & 110.14 & & & & & & & \\
\hline Prob > chi2 & 0.000 & & & & & & & \\
\hline
\end{tabular}

Note: ${ }^{* * *}$ significant at $1 \%$; ${ }^{* *}$ significant at $5 \%$; ${ }^{*}$ significant at $10 \%$

Source: Author's calculations. 